\title{
Selection for reduced muscle glycolytic potential in Large White pigs. I. Direct responses
}

\author{
Pascale Le Roy ${ }^{a}$, Catherine Larzul a*, Jean Gogué ${ }^{\mathrm{b}}$, \\ André Talmant ${ }^{\mathrm{c}}$, Gabriel Monin ${ }^{\mathrm{c}}$, Pierre Sellier ${ }^{\mathrm{a}}$ \\ a Station de génétique quantitative et appliquée, Institut national \\ de la recherche agronomique, 78352 Jouy-en-Josas cedex, France \\ b Institut national de la recherche agronomique, domaine de Galle, \\ 18520 Avord, France \\ c Station de recherches sur la viande, Institut national de la recherche agronomique, \\ Theix, 63122 Saint-Genès-Champanelle, France
}

(Received 3 March 1998; accepted 10 September 1998)

\begin{abstract}
A six-generation selection experiment comprising a selected (S) and a control (C) line has been conducted with the objective of decreasing muscle glycolytic potential in purebred French Large White pigs. Both lines consisted of six to eight sires and about 40 dams per generation, and each dam produced two litters. The selection criterion in the line $\mathrm{S}$ was the in vivo glycolytic potential (IVGP) of the longissimus (ld) muscle, measured on a shot-biopsy sample removed at $75 \mathrm{~kg}$ live weight on boars and gilts from first-parity litters. In addition, the post mortem glycolytic potential (PMGP) of ld, semimembranosus $(\mathrm{sm})$ and semispinalis capitis (sc) muscles was recorded on pigs from second-parity litters slaughtered at $100 \mathrm{~kg}$ live weight. Throughout the experiment, 2981 and 454 animals were recorded for IVGP and PMGP, respectively. A consistent decrease in IVGP and, to a lesser extent, in PMGP was obtained in the line S compared with the line C. Estimates of genetic changes per generation were $-0.18,-0.11,-0.07$ and $-0.09 \mathrm{SD}$ units of the trait for IVGP and PMGP of ld, sm and sc muscles, respectively. The REML heritability estimates were $0.25 \pm 0.02,0.15 \pm 0.06,0.14 \pm 0.06$ and $0.17 \pm 0.05$ for the above four traits, respectively. The REML estimate of genetic correlation of IVGP with PMGP ld $(0.87 \pm 0.15)$ was somewhat higher than those of IVGP with PMGP of sm and sc $(0.56 \pm 0.14$ and $0.68 \pm 0.13$, respectively). It is concluded that downward selection on muscle glycolytic potential may be effective in pigs. (C) Inra/Elsevier, Paris
\end{abstract}

pig / muscle glycolytic potential / selection experiment / genetic parameters

\footnotetext{
* Correspondence and reprints

E-mail: larzul@toulouse.inra.fr
} 
Résumé - Sélection pour abaisser le potentiel glycolytique du muscle chez le porc Large White. I. Réponses directes. Une expérience de sélection comportant une lignée sélectionnée (S) et une lignée témoin (C) a été conduite sur six générations en vue d'abaisser le potentiel glycolytique du muscle chez des porcs de race pure Large White français. L'une et l'autre lignée était constituée de 6-8 pères et d'environ 40 mères par génération, et chaque mère produisait deux portées. Le critère de sélection de la lignée S était le potentiel glycolytique in vivo (IVGP) du muscle longissimus (ld), mesuré sur un échantillon prélevé par biopsie au poids vif de $75 \mathrm{~kg}$ chez les mâles et femelles issus des premières portées. Le potentiel glycolytique post mortem (PMGP) des muscles ld, semimembranosus $(\mathrm{sm})$ et semispinalis capitis $(\mathrm{sc})$ a été mesuré chez des porcs issus des deuxièmes portées abattus au poids vif de $100 \mathrm{~kg}$. Sur l'ensemble de l'expérience, 2981 animaux ont été mesurés pour IVGP et 454 animaux pour PMGP. Un abaissement notable de IVGP et, dans une moindre mesure, de PMGP a été obtenu dans la lignée $\mathrm{S}$, par rapport à la lignée $\mathrm{C}$. Les évolutions génétiques par génération ont été estimées à $-0,18,-0,11,-0,07$ et $-0,09$ unité d'écart type phénotypique du caractère respectivement pour IVGP et PMGP des muscles ld, sm et sc. Les héritabilités, estimées par la méthode REML, ont été respectivement de $0,25 \pm 0,02,0,15 \pm 0,06,0,14 \pm 0,06$ et $0,17 \pm 0,05$ pour ces mêmes caractères. L'estimée REML de la corrélation génétique entre IVGP et PMGP du muscle ld $(0,87 \pm 0,15)$ a été plus élevée que celles existant entre IVGP et PMGP des deux autres muscles (respectivement $0,56 \pm 0,14$ et $0,68 \pm 0,13$ pour les muscles sm et $\mathrm{sc}$ ). Il est conclu que la sélection pour un faible potentiel glycolytique du muscle peut être efficace chez le porc. (c) Inra/Elsevier, Paris

porc / potentiel glycolytique musculaire / expérience de sélection / paramètres génétiques

\section{INTRODUCTION}

From the early 1980s, the French pig industry has become more and more interested in meat quality, particularly in yields of curing-cooking ham processing, the most important part of pig meat transformation. One of the main factors that affect technological meat quality, as defined here by the technological yield of curing-cooking ham processing, is the extent of the muscle pH fall post mortem. In France, a meat quality index was established from post mortem measurements (ultimate $\mathrm{pH}$, reflectance, water holding capacity) made on ham muscles in order to predict technological yield [12]. This index was introduced into the breeding objective to maintain meat technological quality while improving growth rate, lean meat content and feed efficiency. The value of introducing a selection criterion on meat quality measured on live animals was studied earlier from a theoretical point of view [21]. However, such an approach has not been applied so far on a large scale in practical pig breeding except in very particular situations, e.g. halothane phenotype or genotype for proneness to the PSE meat condition. The principle was to choose a criterion easy to measure, heritable, genetically related to meat quality and preferably favourably linked to other production traits under selection. Such a live criterion would allow meat quality to be assessed directly on candidates for selection instead of slaughtered sibs. Experimental results showed that muscle glycolytic potential (GP), an estimator of the intra vitam muscle glycogen content, is closely related to ultimate $\mathrm{pH}$ and meat technological quality [14]. The glycolytic potential is based on the measurement of the main muscle 
glucidic compounds susceptible to transformation into lactic acid through post mortem glycolysis, thus determining the extent of muscle $\mathrm{pH}$ fall. Moreover, this trait can be measured on the longissimus muscle of live animals by shot biopsy [27].

The question was to study the value of the in vivo glycolytic potential measurement as a selection criterion for improving technological quality of meat in a population free of the $\mathrm{RN}^{-}$allele that is known to greatly affect GP $[16,17]$. Thus, a selection experiment aiming at decreasing muscle glycolytic potential, measured on live animals, was carried out from 1988 onwards using pigs from a breed, the French Large White, presumably free of the HAL ${ }^{n}$ and $\mathrm{RN}^{-}$alleles [25].

\section{MATERIALS AND METHODS}

\subsection{Experimental animals}

The animals involved in the present study were purebred French Large White pigs. The base population was constituted by the progeny of a foundation breeding stock consisting of 24 unrelated AI boars and 42 sows. Male and female progeny were randomly allocated to two closed lines. One line (line S) was selected downward for muscle glycogen content as assessed by the in vivo glycolytic potential (IVGP) of the longissimus muscle, whereas the control line (line C) was randomly bred. Both lines were maintained contemporaneously under standardised conditions at the Inra experimental farm of Bourges-Avord.

Starting from the base population, the selection experiment was conducted over six generations from 1989 to 1996. Both lines consisted of six to eight sires and about 40 dams per generation. Each dam was planned to produce two litters at around 12 and 17.5 months of age. After weaning at 4 weeks of age, animals were reared in a post-weaning unit until 10 weeks of age and then moved to fattening pens of 10-12 animals of the same line and the same sex. During the fattening period (from 25 to $100 \mathrm{~kg}$ live weight), animals were given ad libitum access to a commercial standard diet $(17.0 \%$ crude protein, $1.5 \%$ crude fat, $4.5 \%$ crude fibre, $6.8 \%$ ash, $0.85 \%$ lysine, $3.091 \mathrm{Mcal} \mathrm{ME} / \mathrm{kg}$ ).

Replacement boars and gilts were chosen among first-parity litter progeny and the generation interval was about 14 months. In the control line, animals kept for breeding were randomly chosen on a within-family basis. Except in a few cases, each sire was replaced by one of his sons and each dam by one of her daughters. In the selected line, a strict mass selection was practised with a proportion selected of around 8 and $35 \%$ for boars and gilts, respectively. In each generation, the mating scheme for both lines was set up to minimise the increase in the average coefficient of inbreeding of the resulting progeny. The average coefficients of inbreeding within line and generation were computed from the inverse of the numerator relationship matrix [9]. At the end of the experiment, the average coefficient of inbreeding reached $6-8 \%$ in the lines $\mathrm{C}$ and $\mathrm{S}$, respectively.

For assessing the correlated responses to selection for carcass and meat quality traits, one animal per second-parity litter, either a female or a castrated male, was randomly chosen to be slaughtered at $100 \mathrm{~kg}$ live weight in a series 
comprising five or six individuals from each line. Animals slaughtered in a given series were from the same fattening batch. The animals fasted for $16 \mathrm{~h}$ before they were transported for $2 \mathrm{~h}$ to a commercial abattoir. Then, animals were allowed to rest for an additional $18 \mathrm{~h}$ before being slaughtered by electrical stunning and immediate exsanguination.

\subsection{Measurements}

Boars and gilts from first-parity litters were measured for the selection criterion (IVGP) at about $75 \mathrm{~kg}$ live weight. A small muscle sample of about $1 \mathrm{~g}$ was drawn by shot biopsy from the longissimus muscle, at $7-8 \mathrm{~cm}$ behind the $14 \mathrm{th}$ rib on the left side, and around $5 \mathrm{~cm}$ from the dorsal line [27]. Penetration depth was $4.5-5 \mathrm{~cm}$. The biopsy was carried out in the fattening pen without any restraint to ensure minimal stress. The muscle sample was immediately trimmed of skin and fat. For the first four generations, samples were crushed in liquid nitrogen and freeze dried before being homogenised in $10 \mathrm{~mL}$ of $0.5 \mathrm{M}$ perchloric acid. From the fourth generation onwards, muscle samples were directly homogenised in perchloric acid. Then, $0.5 \mathrm{~mL}$ of homogenate was taken for the simultaneous determination of muscle glycogen, glucose and glucose-6-phosphate contents using the enzymatic method of Dalrymple and Hamm [4]. The rest of the perchloric acid homogenate was centrifuged at $2500 \mathrm{~g}$ for $10 \mathrm{~min}$ and the supernatant was used for lactate determination [1]. Glycolytic potential was given by the formula of Monin and Sellier [18], i.e. $\mathrm{GP}=2\{$ [glycogen $]+[$ glucose $]+[$ glucose-6-phosphate $]\}+[$ lactate $]$, and expressed in micromoles equivalent lactate per $g$ of fresh tissue.

Post mortem glycolytic potential (PMGP) was also measured on slaughtered animals from second parity-litters. Thirty minutes after slaughter, 1-g samples of the longissimus, semimembranosus and semispinalis capitis muscles were drawn and homogenised in $10 \mathrm{~mL}$ of $0.55 \mathrm{M}$ perchloric acid for determination of the muscle glycolytic potential as previously described. The choice of these three muscles was based on both their anatomical location and their contractile and metabolic properties, which are known to be different $[13,15]$ : a white muscle from the loin (longissimus) or from the ham (semimembranosus) and a red muscle (semispinalis capitis).

The pigs were reared and slaughtered in compliance with the current national regulations prevailing for commercial slaughtering and animal research experimentation.

Numbers of animals measured for muscle glycolytic potential (IVGP and PMGP) are given in table $I$.

\subsection{Statistical analysis}

Preliminary least squares analyses were performed using the GLM procedure of SAS [22] to estimate the effect of live weight at biopsy or carcass weight as a covariate for IVGP and PMGP, respectively, and the fixed effects of sex, day of measurement nested within generation, generation, line and line $\times$ generation combination. Annual selection differentials were calculated in each line, from differences between the average performance of animals selected as parents and the average performance of all animals measured in each line, weighted 
Table I. Numbers of animals measured for muscle glycolytic potential.

\begin{tabular}{lcccc}
\hline Trait & $\begin{array}{c}\text { Number } \\
\text { of } \\
\text { pigs }\end{array}$ & $\begin{array}{c}\text { Number } \\
\text { of } \\
\text { sires }\end{array}$ & $\begin{array}{c}\text { Number } \\
\text { of } \\
\text { litters }\end{array}$ & $\begin{array}{c}\text { Body weight } \\
\text { at measurement } \\
(\mathrm{kg})^{\mathrm{a}}\end{array}$ \\
\hline $\begin{array}{l}\text { In vivo glycolytic potential } \\
\text { (IVGP) }\end{array}$ & 2981 & 126 & 573 & $75.5(8.2)$ \\
$\begin{array}{l}\text { Post mortem glycolytic potential } \\
\text { (PMGP) }\end{array}$ & 454 & 92 & 397 & $101.1(3.6)$ \\
\hline
\end{tabular}

${ }^{\text {a }}$ In brackets, within-generation standard deviation.

by the proportion of their offspring in the individuals measured in the next generation $[10]$. In the line $\mathrm{C}$, selection differentials were calculated to detect unintentional selection. Cumulative selection differential was calculated as the difference between the cumulative selection differential in the selected line and the cumulative selection differential in the control line to take into account the unintentional selection made in the line $\mathrm{C}$. The annual selection response was measured as the difference between the average performanice of animals in the line $\mathrm{S}$ and the average performance of animals in the line $\mathrm{C}$. The realised heritability for IVGP was determined by regressing the annual selection response against the cumulative selection differential, with regression constrained to pass through the origin, because both lines were taken from the same base population [10]. The approximate standard errors for the annual phenotypic response and for the realised heritability were calculated accounting for drift variance and measurement error variance $[10,11]$.

For the genetic analysis, the model included live weight for IVGP or carcass weight for PMGP as a covariate, sex as a fixed effect, biopsy date (75 levels) for IVGP or slaughter series (39 levels) for PMGP and animal additive genetic values as random effects. For IVGP, litter effect was also taken into account as a random effect. Litter effect was not included in the model for PMGP because only one slaughtered animal per second-parity litter was recorded for this trait.

Variance and covariance components were estimated using a restricted maximum likelihood (REML) procedure applied to a four-trait individual animal model with missing data. All the ancestors of the recorded animals, up to the grand-parents of the base population from which the control and selected lines were derived, were taken into account for establishing the numerator relationship matrix of the animals. There were 3701 individuals in the pedigree file. The estimation of genetic parameters was performed with version 3.2 of the VCE computer package, using a quasi-Newton algorithm with exact first derivatives to maximise the log likelihood [20]. Heritability $\left(h^{2}\right)$ was computed as the additive genetic variance divided by the adjusted phenotypic variance. Approximate standard errors of variance components and genetic parameters were obtained from the inverse of an approximation of the Hessian matrix when convergence was reached [24].

Additive genetic breeding values were estimated in a four-trait analysis using the BLUP (best linear unbiased predictor) methodology applied to an individual animal model as previously described for REML analysis. The 
REML-estimated genetic parameters were used in the model. The analysis was performed using the PEST computer package [8]. The response to selection was estimated from the within-generation line difference (selected-control) for average predicted breeding values (genetic response). When averaging predicted breeding values for a trait, only individuals recorded for that trait were taken into account. For simplification, the approximate standard errors for the annual $\mathrm{S}-\mathrm{C}$ differences were calculated for each trait with REMLestimated parameters, considering that animal breeding values were computed in univariate analyses [26].

Coheritabilities for the selection criterion (IVGP) with the PMGPs were calculated from REML estimates. Their standard errors were approximated from the standard errors of parameters using the first order term of a Taylor expansion.

\section{RESULTS}

\subsection{Selection differentials}

Table II gives the number of animals measured and selected, as well as the selection differentials, by line, generation and sex, and the selection intensity (standardised selection differential) by line and generation. In line S, selection on females became really effective from generation 3 and selection on males became more intense from the same generation onwards. It should be pointed out that an unintended selection differential occurred in line $\mathrm{C}$ at generation 3 and, to a lesser extent, at generation 5 . When randomly choosing control boars at generation 3 , it happened that one boar showing the lowest IVGP value was kept.

\subsection{Responses to selection}

The line differences (selected-control) for phenotypic means and average breeding values across generations are shown in figure 1. For IVGP, the phenotypic and genetic line differences are very similar whatever the generation. A significant response was observed for IVGP from generation 3 onwards in the selected line. At the last generation, the line difference for IVGP average breeding values was $-26.4 \pm 7.3 \mu \mathrm{mol} / \mathrm{g}$ fresh tissue, i.e. -1.15 phenotypic standard deviation units of the trait. In line S, a decrease in PMGP was observed in the three muscles. At the last generation, the differences between the average breeding values of the selected and control lines were $-14.4 \pm$ $5.4,-7.9 \pm 4.7$, and $-8.1 \pm 3.8 \mu \mathrm{mol} / \mathrm{g}$ fresh tissue for the PMGP of the longissimus, semimembranosus and semispinalis capitis muscles, respectively. When considering the regression of line difference on generation number, the genetic responses to selection per generation were $-4.2 \mu \mathrm{mol} / \mathrm{g}$ for IVGP and $-2.5,-1.4$ and $-1.3 \mu \mathrm{mol} / \mathrm{g}$ per generation for the PMGP of the longissimus, semimembranosus and semispinalis capitis muscles, respectively.

\subsection{Heritabilities}

The realised heritability $\left(h^{2}\right)$ value of IVGP was $0.21 \pm 0.05$ and was slightly lower than the REML $h^{2}$ estimate of 0.25 (table III). Estimated $h^{2}$ of PMGP 


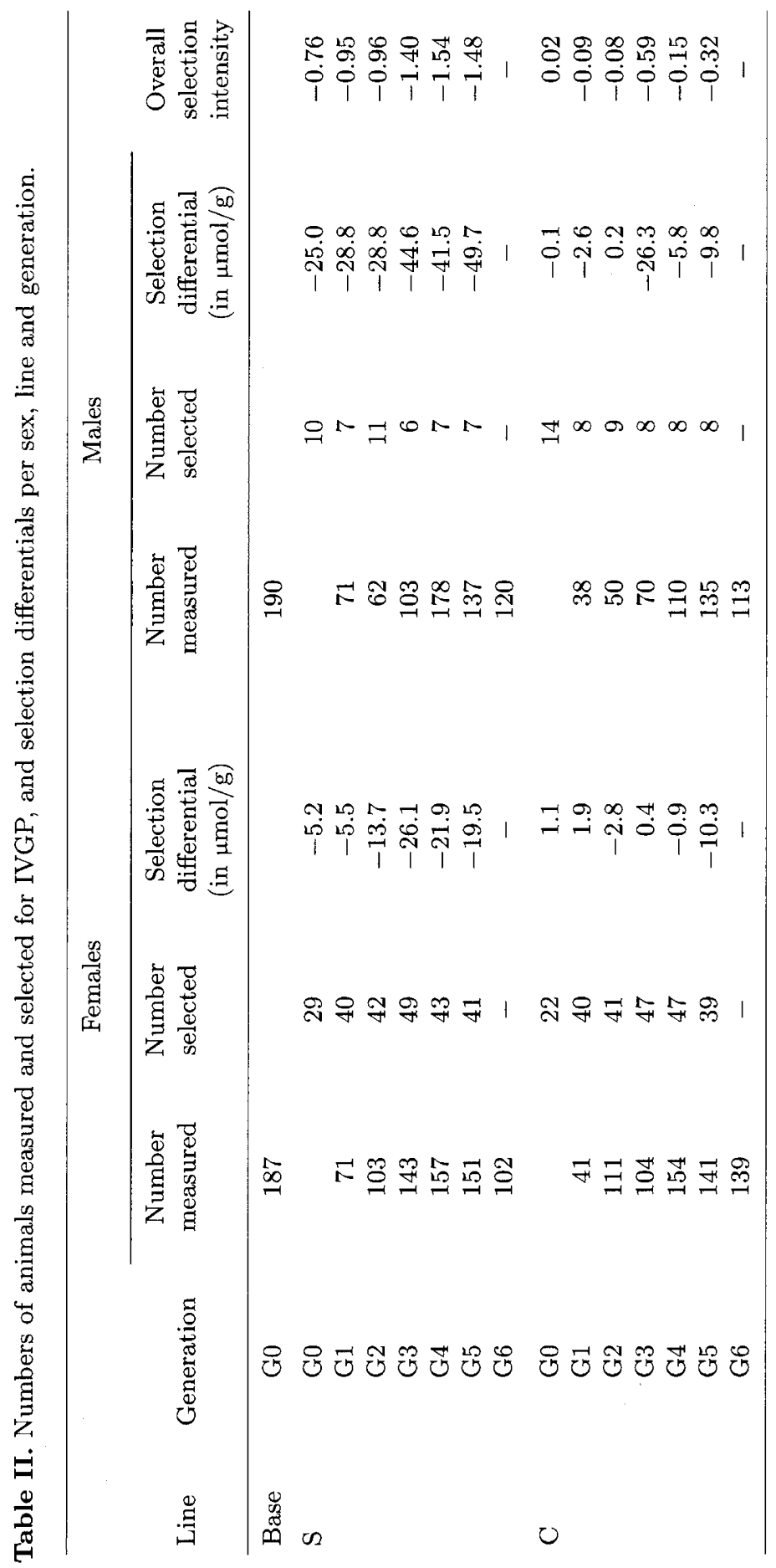



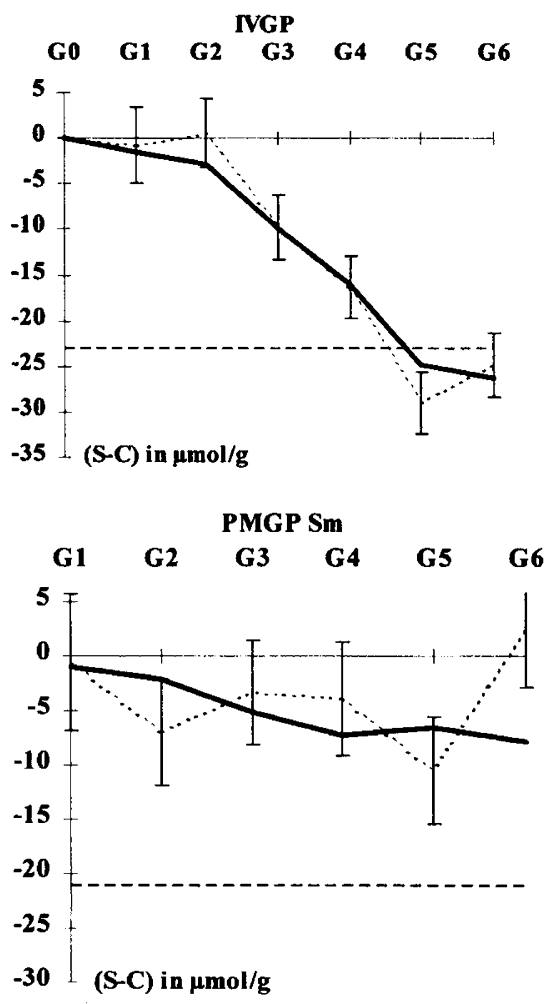
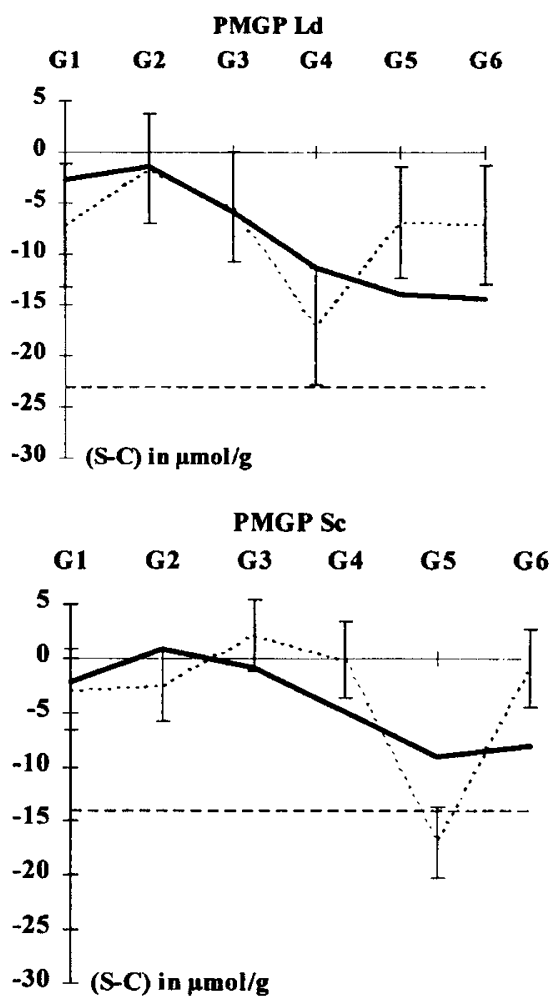

Figure 1. Differences across generations between selected (S) and control (C) lines for in vivo glycolytic potential of the longissimus muscle (IVGP) and post mortem glycolytic potential of the longissimus (PMGP ld), semimembranosus (PMGP sm) and semispinalis capitis (PMGP sc) muscles. ......, phenotypic trends; __, genetic trends; - - - , one SD unit.

was of the same magnitude for the three muscles studied (0.14-0.17). The part of the variance of PMGP due to slaughter date was larger for the semispinalis capitis muscle $(31 \%)$ than for the semimembranosus and longissimus muscles $(20 \%)$. The part of the variance due to the biopsy date for IVGP of the longissimus muscle $(26 \%)$ was slightly larger than that due to the slaughter date for PMGP of the same muscle.

\subsection{Correlations}

Phenotypic and genetic correlations are given in table $I V$. Genetic correlations $\left(r_{A}\right)$ between IVGP (longissimus) and PMGP decrease from the longissimus muscle to semispinalis capitis muscle and to the semimembranosus muscle. As could be expected, the highest genetic correlation was found between IVGP and PMGP measured in the longissimus muscle. These two measurements, even though they were not made under the same conditions (live weight, environment), were made on the same muscle at close locations. The lowest genetic correlation $(0.56 \pm 0.14)$ was found between IVGP and PMGP of the 
Table III. Estimates of least squares means by sex, phenotypic standard deviation $\left(\sigma_{p}\right)$, heritability $\left(h^{2}\right)$, litter effect $\left(c^{2}\right)$ and date of measurement effect $\left(s^{2}\right)$ for in vivo (IVGP) and post mortem muscle glycolytic potential (PMGP), in $\mu \mathrm{mol} / \mathrm{g}$ of fresh tissue, for the longissimus (ld), semimembranosus ( $\mathrm{sm}$ ) and semispinalis capitis (sc) muscles.

\begin{tabular}{|c|c|c|c|c|c|}
\hline Item & & IVGP ld & PMGP ld & PMGP sm & PMGP sc \\
\hline Means by sex $( \pm \mathrm{SE})$ & $\begin{array}{c}\text { boars } \\
\text { gilts } \\
\text { castrates }\end{array}$ & $\begin{array}{l}183 \pm 1 \\
193 \pm 1\end{array}$ & $\begin{array}{l}118 \pm 2 \\
113 \pm 2\end{array}$ & $\begin{array}{l}101 \pm 1 \\
100 \pm 1\end{array}$ & $\begin{array}{l}48 \pm 1 \\
45 \pm 1\end{array}$ \\
\hline$\sigma_{p}$ & & 23 & 23 & 21 & 14 \\
\hline$h^{2} \pm \mathrm{SE}$ & & $0.25 \pm 0.02$ & $0.15 \pm 0.06$ & $0.14 \pm 0.06$ & $0.17 \pm 0.05$ \\
\hline$c^{2} \pm \mathrm{SE}$ & & $0.09 \pm 0.01$ & & & \\
\hline$s^{2} \pm \mathrm{SE}$ & & $0.26 \pm 0.03$ & $0.20 \pm 0.03$ & $0.20 \pm 0.03$ & $0.31 \pm 0.04$ \\
\hline
\end{tabular}

Table IV. Estimates of phenotypic correlations ${ }^{\text {a }}$ (below diagonal), genetic correlations ( $\pm \mathrm{SE}$ ) (above diagonal), and coheritabilities ( $\pm \mathrm{SE})$.

\begin{tabular}{lccr}
\hline Trait & PMGP ld & PMGP sm & \multicolumn{1}{c}{ PMGP sc } \\
\hline In vivo glycolytic potential (IVGP) & $0.87 \pm 0.15$ & $0.56 \pm 0.14$ & $0.68 \pm 0.13$ \\
longissimus (PMGP ld) & & $0.83 \pm 0.13$ & $0.48 \pm 0.25$ \\
semimembranosus (PMGP sm) & $0.65^{* * *}$ & & $-0.08 \pm 0.34$ \\
semispinalis capitis (PMGP sc) & $0.51^{* * *}$ & $0.52^{* * *}$ & \\
\hline Coheritability with IVGP & $0.17 \pm 0.05$ & $0.11 \pm 0.03$ & $0.14 \pm 0.03$ \\
\hline
\end{tabular}

${ }^{\mathrm{a}}$ Level of significance: ${ }^{* * *} P<0.001$.

semimembranosus muscle, though the longissimus and semimembranosus muscles are of similar metabolic type. This correlation could indicate that muscles were not reacting in the same way during the slaughter procedure and/or the semimembranosus muscle is less homogeneous than the longissimus muscle.

The phenotypic correlations between PMGPs of the three muscles studied were of the same order $(0.5-0.6)$. However, the $r_{A}$ estimates for PMGP were strongly dependent on the two muscles considered. They were very low $(-0.08 \pm 0.34$ between semimembranosus and semispinalis capitis PMGPs) to very high ( $0.83 \pm 0.13$ between longissimus and semimembranosus PMGPs), the genetic correlation between longissimus and semispinalis capitis PMGPs being intermediate $(0.48 \pm 0.25)$. Coheritabilities (table IV) were of the same order for PMGPs of the three muscles. 


\section{DISCUSSION}

During the experiment, over all generations, we observed a significant genetic change in the in vivo glycolytic potential observed in the selected line, with a significant difference between the two lines at the 6th generation. The absence of the $\mathrm{RN}^{-}$allele, known to largely increase IVGP [17], was reinforced by the absence of high IVGP values in the base population. Genetic response differed from one generation to another. The lack of response during the first two generations may be explained by the intensity of selection which was not as high as initially planned. The explanation is to be found in the number of animals measured and selected and in the way of selecting parents. In the first generations, the number of males and females recorded for IVGP was lower than in the following generations. And during these first generations, parents were not selected among all the batches because, at time of mating, animals of the last batch had not reached puberty. To avoid this problem in the next generations, generation interval was increased. Then, the response to selection was much greater in the following generations.

The estimated value of heritability for in vivo glycolytic potential of the longissimus muscle is much lower than values reported for the same trait by Le Roy et al. [16]. In the latter study, the $\mathrm{RN}^{-}$allele was segregating in the two composite lines involved, leading to very high values of heritability $(0.86-0.90)$. The heritability values estimated by Burlot [2] in the same lines taking into account the RN genotype effect were of medium range (0.32-0.42), and only slightly higher than the present estimated value.

The proportion of variance due to slaughter date for PMGP of the longissimus muscle is in agreement with that estimated by de Vries et al. [6] for ultimate $\mathrm{pH}$ of the same muscle $(0.22)$. In earlier studies [3, 23], the proportion of variance due to slaughter date was found to be even larger for ultimate $\mathrm{pH}$ of longissimus and adductor femoris (about 0.40), but these estimates were probably inflated by other factors (e.g. genetic) than the slaughter date effect itself. Thus, slaughter date seems to affect to the same extent muscle glycogen content and ultimate $\mathrm{pH}$ of longissimus muscle. In the present study, glycolytic potential of the semispinalis capitis muscle was more affected by slaughtering conditions than PMGP of white muscles.

The differences between responses obtained for IVGP on the one hand and PMGP of the three muscles on the other hand could be explained by the fact that IVGP and PMGP are different traits: IVGP is a measurement of the muscle glycogen content under minimal stress conditions whereas PMGP is a measurement of muscle glycogen content in animals stressed by pre-slaughtering conditions. Moreover, the average value of IVGP is higher than the average value of PMGP (table III) in the longissimus (190 and $115 \mu \mathrm{mol} / \mathrm{g}$ fresh tissue, respectively). One part of the difference between measurements could be due to difference in live weight at measurement: as shown by Dalrymple et al. [5], muscle glycogen content tended to decrease when animals grew older. However, the muscle glycolytic potential is essentially lowered by all the treatments applied before slaughter (fasting, transportation, resting time at the abattoir, etc.) known to deplete muscle glycogen content (for review, Fernandez and Tornberg [7]). The phenotypic correlation between IVGP and PMGP in the 
longissimus muscle is known to be low $(0.20)$ for animals free of the $\mathrm{RN}^{-}$ allele [14].

\section{CONCLUSION}

The significant genetic changes in the in vivo glycolytic potential observed in the selected line and the medium heritability value found for this trait allow it to be concluded that it is possible to introduce this trait as a selection criterion [14]. From estimated genetic correlations with post mortem glycolytic potential, it appears that selection for decreasing in vivo glycolytic potential in the longissimus muscle would result in a lesser decrease in post mortem glycolytic potential. However, the magnitude of the correlated genetic change in the latter trait depends on the metabolic type of the muscle considered. The consequences of downward selection on IVGP for meat quality and production traits are developed in subsequent papers.

\section{ACKNOWLEDGEMENTS}

This work was part of the project 'régulation du potentiel glycolytique du muscle chez le porc' and was supported by grants from the Inra-Agrobio programme initiated in 1990. Thanks are due to Pierre Vernin (SRV, Theix), Hervé Lagant (SGQA, Jouy-en-Josas) and the staff of the pig experimental unit in Bourges-Avord for their technical assistance. Comments and suggestions of one referee were appreciated.

\section{REFERENCES}

[1] Bergmeyer H.U., in: Bourne G.H. (Ed.), Methods of Enzymatic Analysis, Academic Press, New York, 1974, pp. 1127-1196.

[2] Burlot T., Étude de la variabilité génétique du potentiel glycolytique du muscle dans deux lignées synthétiques porcines, Mémoire de fin d'études, ISA de Beauvais, 1994, 43 pp.

[3] Charpentier J., Monin G., Ollivier L., Correlations between carcass characteristics and meat quality in Large White pigs, in: Proceedings of the 2nd International Symposium on Condition and Meat Quality of Pigs, Pudoc, Wageningen, 1971, pp. $255-260$.

[4] Dalrymple R.H., Hamm R., A method for the extraction of glycogen and metabolites from a single muscle sample, J. Food Technol. 8 (1973) 439-444.

[5] Dalrymple R.H., Kastenschmidt L.L., Cassens R.G., Glycogen and phosphorylase in developing red and white muscle, Growth 37 (1973) 19-34.

[6] De Vries A.G., van der Wal P.G., Lang T., Eikelenboom G., Merks J.W.M., Genetic parameters of pork quality and production traits in Yorkshire populations, Livest. Prod. Sci. 40 (1994) 277-289.

[7] Fernandez X., Tornberg E., A review of the causes of variation in muscle glycogen content and ultimate pH in pigs. J. Muscle Foods 2 (1991) 209-235.

[8] Groeneveld E., Kovac M., A generalized computing procedure for setting up and solving mixed linear models, J. Dairy Sci. 73 (1990) 513-531.

[9] Henderson C.R., A simple method for computing the inverse of a numerator relationship matrix in prediction of breeding values, Biometrics 32 (1976) 69-83.

[10] Hill W.G., Estimation of realised heritabilities from selection experiments. II. Selection in one direction, Biometrics 28 (1972) 767-780. 
[11] Hill W.G., Design of quantitative genetics selection experiments, in: Robertson A. (Ed.), Selection Experiments in Laboratory and Domestic Animals, Commonwealth Agricultural Bureaux, Slough, UK, 1980, pp. 1-13.

[12] Jacquet B., Sellier P., Runavot J.P., Brault D., Houix Y., Perrocheau C., Gogué J., Boulard J., Prédiction du rendement technologique de la fabrication du «jambon de Paris» à l'aide de mesures prises à l'abattoir, in: $16^{\text {es }}$ Journées de la recherche porcine en France, Paris, 1-3 février 1984, Institut technique du porc, Paris, 1984, pp. $49-58$.

[13] Laborde D., Talmant A., Monin G., Activités enzymatiques métaboliques et contractiles de 30 muscles du Porc. Relations avec le $\mathrm{pH}$ ultime atteint après la mort, Reprod. Nutr. Dev. 25 (1985) 619-628.

[14] Larzul C., Le Roy P., Monin G., Sellier P., Variabilité génétique du potentiel glycolytique du muscle chez le porc, Inra Prod. Anim. 11 (1998) 183-197.

[15] Lefaucheur L., Le Dividich J., Mourot J., Monin G., Ecolan P., Krauss D., Influence of environmental temperature on growth, muscle and adipose tissue metabolism, and meat quality in swine, J. Anim. Sci. 69 (1991) 2844-2854.

[16] Le Roy P., Przybylski W., Burlot T., Bazin C., Lagant H., Monin G., Étude des relations entre le potentiel glycolytique du muscle et les caractères de production dans les lignées Laconie et Penshire, in: $26^{\text {es }}$ Journées de la recherche porcine en France, Paris, 1-3 février 1994, Institut technique du porc, Paris, 1994, pp. 311-314.

[17] Le Roy P., Monin G., Elsen J.M., Caritez J.C., Talmant A., Lebret B., Lefaucheur L., Mourot J., Juin H., Sellier P., Effect of the RN genotype on growth and carcass traits in pigs, in: Van Arendonk J.A.M. (Ed.), Book Abstr. of the 47th E.A.A.P. Ann. Meeting, Wageningen Pers, Wageningen, the Netherlands, 1996.

[18] Monin G., Sellier P., Pork of low technological quality with a normal rate of muscle $\mathrm{pH}$ fall in the immediate post mortem period: the case of the Hampshire breed, Meat Sci. 13 (1985) 49-63.

[19] Monin G., Mejenes-Quijano A., Talmant A., Sellier P., Influence of breed and muscle metabolic type on muscle glycolytic potential and meat $\mathrm{pH}$ in pigs, Meat Sci. 20 (1987) 149-158.

[20] Neumaier A., Groeneveld E., Restricted maximum likelihood estimation of covariances in sparse linear models, Genet. Sel. Evol. 30 (1998) 3-26.

[21] Ollivier L., Potier D., L'amélioration de la qualité de la viande porcine par la sélection, in: $7^{\text {es }}$ Journées de la recherche porcine en France, Paris, 19-21 février 1975, Institut technique du porc, Paris, 1975, pp. 293-302.

[22] $\mathrm{SAS}^{\circledR}, \mathrm{SAS}^{\circledR}$ Inst. Inc., Cary, NC, 1985.

[23] Scheper J., Influence of environmental and genetic factors on meat quality, Acta Agric. Scand. suppl. 21 (1979) 20-31.

[24] Searle S.R., Casella G., Mc Culloch C.E., Variance Components, John Wiley \& Sons, New York, NY, 1992.

[25] Sellier P., Monin G., Genetics of pig meat quality, a review, J. Muscle Foods 5 (1994) 187-219.

[26] Sorensen D.A., Kennedy B.W., Analysis of selection experiments using mixed model methodology, J. Anim. Sci. 63 (1986) 245-258.

[27] Talmant A., Fernandez X., Sellier P., Monin G., Glycolytic potential in Longissimus dorsi muscle of Large White pigs as measured after in vivo sampling, in: Proceedings of the 35th Int. Cong. Meat Sci. and Technol., Copenhagen, Danish Meat Research Institute, Roskilde, 1989, pp. 1129-1131. 